\title{
UNIFORMITY OF APPLICATION OF THE EU CUSTOMS LAW: PROBLEMATIC ASPECTS IN THE BALTIC STATES
}

\author{
Gediminas Valantiejus ${ }^{1}$, Saulius Katuoka ${ }^{2}$ \\ ${ }^{I}$ Professional Law Partnership ,iLAW“(http://www.en.ilaw.legal)/Mykolas Romeris University, Vilnius, \\ Lithuania,gvalantiejus@mruni.eu \\ ${ }^{2}$ Mykolas Romeris University, Vilnius, Lithuania, skatuoka@mruni.eu
}

\begin{abstract}
Research purpose. The EU Customs Law is a significant branch of the EU substantive law. On the basis of the Union Customs Code (UCC; Regulation [EU] No. 952/2013) and the Combined Nomenclature of the European Union (Regulation [EU] No. 2658/87 and its Annexes), it regulates the international trade of the European Union and its Member States with the third countries, in particular the taxation of the international trade operations by applying the customs duties/tariffs. However, after the adoption of the UCC, which imperatively requires all the customs administrations of the EU Member States to work as one, the problem of the uniform application of the EU customs law remains very important. Therefore, the authors analyse the practice of the Baltic States (i.e. Republics of Estonia, Latvia and Lithuania) in this area, based on the case law of the Court of Justice of the European Union (CJEU) in cases involving references to the CJEU by the national courts of different Baltic States.

Design/Methodology/Approach. The authors used the thematic analysis method and the method of generalisation of professional (judicial) practice as the basis of the chosen methodology and its design. Therefore, first of all, the authors have selected the judicial cases of the CJEU (in the period from 2010 to 2018) related to a certain theme - customs duties. Second, the authors compared the practice of the CJEU in such cases, which are attributable to the relevant EU Member State in order to identify the problems of uniformity in the application of the EU customs law (specific to the different Baltic States). Finally, by using comparative insights and comparative method, the authors present proposals for the improvement of legal regulation to ensure the compatibility of national rules and practices with the EU law.
\end{abstract}

Findings. During the investigation, the authors established that the problems of the uniform application of the EU customs law in the Baltic States arose in specific areas. Such areas were tariff classification of goods, determination of the origin and value of goods (in the case of Latvia), regulation of customs procedures (in the case of Estonia), customs duties and other import taxes preferences (in the case of Lithuania). At the same time, it was established that the national courts of the Republic of Lithuania were the least active in ensuring co-operation with the CJEU this area, which could have been caused by the improper national legal regulations.

Originality/Value/Practical implications. The authors present (after the assessment of the experience of the Baltic States) the proposals for the improvement of both the legal regulations of the EU customs law as well as national legal regulations (in particular - in the Republic of Lithuania) to improve the areas that cause systemic irregularities of the uniform regulation of the international trade regulatory measures of the European Union. Whilst some of the similar studies were completed in the recent years (e.g. Limbach 2015), they do not provide a detailed comparative analysis of the issues that were investigated, specifically considering the situation in the Baltic States.

Keywords: international trade; customs duties; Court of Justice of the EU; national courts; Baltic States

JEL codes: F13; K34

\section{Introduction}

The topicality of the research. The policies of the European Union and the areas of its competences has traditionally focused on the harmonious regulation of external trade with the third countries and ensured the effective functioning of the customs union. For this reason, the EU Common Customs Tariff (uniform customs duty rates used for the taxation of international trade in goods) is usually considered 
(see, e.g. Kolliker, 2006, Craig and de Burca, 2015) as a guarantee of the effectiveness of the EU trade and other external policies (Common Commercial Policy). Therefore, from a strategic point of view, the objectives of the European Union as a customs union include, inter alia, improving the regulatory framework of international trade. They also include ensuring both the continued protection of the fiscal and other economic interests of the European Union and supporting the initiatives needed to strengthen the competitiveness of the European Union in international trade markets (see Communication from the Commission to the European Parliament, the Council and the European Economic and Social Committee 'On the State of Customs Union', $\operatorname{COM}(2012) 791$ final, 2012). It is noteworthy to mention that the essential instrument that ensures accomplishment of such goals and the correct application of the EU Common Customs Tariff is the Union Customs Code (UCC). It was adopted on 9 October 2013 and has entered into force since the 1 May 2016 (see Regulation No. 952/2013 of the European Parliament and of the Council of 9 October 2013 laying down the UCC, 2013). The importance of the UCC for the application of customs duties in the European Union is fundamental, especially regarding the factors for the calculation of customs duties such as the value of goods, their origin as well as customs procedures and administration of customs duties and other import taxes (by customs authorities). For example, the UCC requires that all customs administrations in the EU Member States should work as one administration (see Article 3 of the UCC), which is essential for the uniform regulation of international trade with the third countries in all the EU Member States.

It should be noted that the provisions of the UCC itself have been developed in advance by taking into account the fact that the principle of subsidiarity does not apply to the regulation of legal relations related to the collection and calculation of customs duties. Their regulation falls within the exclusive competence of the European Union and belongs to the area of the EU Common Commercial Policy (see 'Explanatory Memorandum to $\operatorname{COM}(2012) 64$ - Union Customs Code', 2012 [Chapter 3.6]). Also, the UCC itself now directly declares the need to 'promote further the uniform application of customs legislation' (para. 15 of the preamble to the UCC) and 'to ensure an equivalent level of customs control throughout the Union so as not to give rise to anti-competitive behaviour at the various Union entry and exit points'. Thus, according to the provisions of the UCC and current practice of Court of Justice of the European Union (see cases Ioannis Christodoulou and Others v. Elliniko Dimosio, 2013; HARK GmbH \& Co. KG, Kamin-und Kachelofenbau v. Hauptzollamt Duisburg, 2013; Steinel Vertrieb GmbH v. Hauptzollamt Bielefeld, 2013), the primary objective of the Member States and their institutions (including customs administrations and other national authorities such as national courts) is to ensure uniform application of the EU customs legislation. Such objective applies to both the areas of calculation of customs duties and the implementation of other regulatory measures towards the international trade operations.

It is essential to note that, although regulation of customs duties (as it was mentioned before) is included into the scope of the EU Common Commercial Policy and fall under an exclusive competence of the European Union, on the practical level, the EU Member States compete with each other in the areas of their administration/application. For example, they usually seek to collect the most significant possible amount of customs duties and other import taxes, which are calculated based on the EU customs legislation (see Radžiukynas, Belzus, 2008; Baronaitè, 2010; Sarapinienè, Avižienis, 2008; Truel, Maganaris, 2015; Limbach, 2015, Walsh, 2015). Therefore, they pursue different practices for the implementation of control procedures (applicable to the collection of customs duties) and adopts more comprehensive sources' national legislation that regulates in detail the application of specific provisions of the EU customs legislation (by taking into account the local situation and the peculiarities of the functioning of national customs authorities). It is important to note that the possibility to apply national provisions in such situations is also directly mentioned in the UCC (Art. 5, para. 2) and in other sources of the EU customs law (Communication from the Commission to the European Parliament, the Council and the European Economic and Social Committee 'On the State of Customs Union', COM(2012) 791 final, 2012; para. 1.4.2). However, such existing situation may also lead to cases when the EU customs law is applied (interpreted) differently in the individual EU Member States, for example, in their national courts that settle disputes concerning the decisions of national customs administrations. Thus it also creates preconditions for the uneven implementation of the EU customs policy in the EU Member States. 
Moreover, it also threatens the consistent application of the EU Common Customs Tariff that should be applicable across the European Union towards goods originating in the third countries. Therefore, it is essential to look for legal solutions in the Member States to create a business-friendly legal environment, to promote investments related to the development of international trade with due respect to the requirements of the EU Common Commercial Policy and the EU customs law. For this reason, the authors of this article formulated the following aim of the research to identify the problems of uniformity in the application of the EU customs law (specific to the different Baltic States) and to present proposals for the improvement of legal regulation to ensure the compatibility of national rules and practices with the EU law. To achieve this goal, the author's have applied certain specific research methods, such as the methods of thematic analysis and the method of generalisation of professional practice/experience. To complete the thematic analysis of the selected topic of the research and to generalise its results, the authors have selected the judicial cases of the Court of Justice of the European Union (CJEU; in the period from 2010 to 2018) related to specific topic - application of customs duties in the Baltic States (Lithuania, Latvia and Estonia). The authors also compared the practice of the CJEU in such cases (in total -13 of them). On the basis of this comparative analysis and generalisation of the judicial practice, the authors identified and presented the problems of uniformity in the application of the EU customs law (specific to the different Baltic States). They also presented proposals for the further improvement of substantive EU law itself and the national laws of the Member States (particularly - the Republic of Lithuania).

Main research results. During the investigation, the authors established that the problems of uniform interpretation of the EU customs law in the Baltic States are related to all significant factors, relevant to the proper calculation of customs duties and application of the EU Common Customs Tariff. They, first of all, include cases related to the proper tariff classification of goods, determination of the origin and value of goods (in the cases originating in the Republic of Latvia). Second, they include regulation of customs procedures (in the cases originating in the Republic of Estonia), and, third, they include the application of exemptions/preferences of customs duties and other import taxes (especially in the cases originating in the Republic of Lithuania). At the same time, it was established that the national courts of the Republic of Lithuania and the Republic of Estonia were the least active in ensuring co-operation with the CJEU this area, which could have been caused by the improper national legal regulations, at least in the cases involving Lithuania.

\section{Literature Review}

The scientific novelty of the research that is presented in this article can be justified by the fact that the national level of regulation and application of customs duties in the individual Member States was not comprehensively analysed in the scientific literature. During the past five-year period (since 2013), only a limited number of such studies completed by other authors were published and they only partially described the experience of some individual EU Member States, such as the Federal Republic of Germany (analysed by Limbach, 2015), Kingdom of the Netherlands and the French Republic (analysed by Truel and Maganaris, 2015), the United Kingdom (analysed by Lyons, 2015), Slovak Republic (analysed by Novačkova, 2013). However, in the context of the Baltic States, namely, the Republic of Lithuania, similar types of legal research were not completed. For example, although the problems related to competition in a field of taxation were analysed in the doctoral dissertation of M. Lukas, the author of the dissertation did not address the issues of competition between the EU Member States in the area of application of customs duties. Also, the author did not describe related national regulatory practices by merely stating the importance of customs duties in the national tax systems are now declining (see Lukas, 2013). So in this respect, the research presented in this article complements the other above-mentioned foreign and Lithuanian authors' investigations where the national context of the application of customs duties in the EU Member States was mentioned but has not been explored in detail. It should also be noted that even in a longer perspective, the problem of uniform application of customs duties as an international trade regulatory measures of the European Union and the associated legal or regulatory issues were analysed only fragmentary in the national legal doctrine. Almost no attempts were made to assess them from the perspective of the EU customs law and to relate them to the practice of the settlement of tax disputes and practice of administration of taxes. This type of research, 
covering not only the theoretical aspects of the application of customs legislation but also the existing legal practice, was only carried out by the following authors: Radžiukynas (2003, 2005), Gurevičiené (2005), Medelienè and Paulauskas (2008) and Baronaite (2010). However, most of these studies have been completed only immediately before or after the entry of the Republic of Lithuania to the European Union (in 2004).

On the other hand, later (in the past decade since 2011), no practical, applied research studies related to the application of customs duties (in the Republic of Lithuania) were completed, although, at the same time, other types of taxes and regulatory issues related to them were analysed in the national legal doctrine (Puzinskaite, Klišauskas, 2012; Puzinskaite, 2013; Lučinskienè, Rimkus, 2010; Medelienè, 2012). As an exception, its is possible to mention studies of Bikelis $(2012,2013,2015,2017)$ that examined problems related to the application of sanctions for offenses of customs legislation. It is also possible to mention publications of A. Medelienè, A. Paulauskas, M. Lukas, V. Vasiliauskas, A. Milinis, and K. Pranevičienè. These publications analysed the individual tax dispute cases in which the legality of calculation of customs duties was examined and the national courts referred to CJEU or cases where the validity of the EU legislation (legal acts of EU itself) was questioned (see Medeliene, Vasiliauskas, 2012; Lukas, Medelienė, Paulauskas, 2014; Milinis, Pranevičienė, 2016). The situation in other Baltic States (the Republic of Estonia and Republic of Latvia) was assessed (in studies prepared in English language) only in a fragmented way. For example, only some of the problems related to the uniform application of the EU customs legislation in these countries were mentioned (by taking into account referrals of national courts to the CJEU) in the articles of Rodriguez and Dulguerova (2013) and Gavier and Rovetta (2011). However, these articles present only the problems involving one particular area of the EU customs law, that is, tariff classification of goods and does not mention any other issues, even if they were reflected in the practice of the CJEU, involving cases from the Republic of Latvia and Estonia. Besides, there are no complex or comparative studies in this field, which compare the situation in the different Baltic States and makes the generalisations of the existing situation or proposes ways to solve existing problems. Therefore, the authors seek to fill this gap and to provide a comprehensive comparative analysis of the situation in all Baltic States and on this basis to provide the proposals how to ensure the consistent application of the EU customs legislation (both at the EU and the national level, especially in the Republic of Lithuania).

\section{Methodology}

The following research methods were applied to study and investigate the application of the EU customs law in the Baltic States: logical-analytical (analysis and synthesis), systematic, comparative, statistical, historical and the method thematic analysis as well as generalisation of professional experience (case law/legal practice). The sophisticated application of these methods was essential to ensure the correctness and reliability of the generalisations and conclusions made by the authors. The main research methods were comparative method and method of thematic analysis - this aspect of the research design was essential, and it reflects the paradigm of the study as other general methods of scientific research that were used in this article complement them. The methodological basis of the research carried out was a qualitative study, which means that the data were collected in a verbal (textual) form, expressed in textual statements or categories and evaluated subjectively. To sort out the data for the investigation and to summarise the experience of all the Baltic States in the researched area during the investigated period (2010-2018), the authors have selected the cases of the CJEU in which the national courts of the Baltic States referred to this EU Court. All of these cases have the same characteristic - in all of them, the national courts have raised the questions regarding the explanation of the EU customs legislation. To perform the thematic analysis of these cases and the texts of the CJEU's decisions in them (see Patton, 1990, regarding the methodological assumptions of such types of research), the cases were divided into three main themes/topics. Such themes/topics were: 1 . Cases involving the Republic of Latvia; 2-3. Cases involving the Republic of Lithuania and the Republic of Estonia). Each topic/theme was analysed in detail according to the sub-themes/sub-topics that further describe them, such as ' 1.1 . Cases related to the tariff classification of goods'; '1.2. Cases related to the regulation of customs procedures'; '1.3. Cases related to the customs valuation of goods'; '1.4. Cases related to the customs origin of goods'; '2-3(1). Cases related to the regulation of exemptions from customs duties'. 
All in all, based on the official information in the database of the CJEU case law, the authors have selected and analysed 13 of such cases, 2 of which involved Lithuania and Estonia (Cases C-250/11 and $\mathrm{C}-3 / 13$, all of them were related to the regulation of exemptions from customs duties). Eleven cases involved Latvia, and they are listed below:

1) Cases C-382/09, C-558/11, C-233/15, C-547/13, C-199/09 (all the previously mentioned cases were related to the tariff classification of goods);

2) Cases C-571/12, C-286/15, C-154/16 (all the previously mentioned cases were related to the regulation of customs procedures);

3) Cases C-46/16, C-430/14 (the case was related to the customs valuation of goods) and C-47/16 (the case was related to the determination of customs origin of goods).

Finally, the legal problems raised in all these cases were compared with an existing case law of the CJEU (involving other Member States of the European Union) and, as authors mainly focussed on the situation in the Republic of Lithuania, with the relevant existing national judicial practice of national courts. On the basis of this comparative analysis, the authors provided the recommendations for the improvement of the EU customs law and national laws (particularly in the Republic of Lithuania) and presented them in the following sections of the article.

\section{Results}

\section{Cases involving the Republic of Latvia.}

1.1. Cases related to the tariff classification of goods: It should be noted that the tariff classification of goods is one of the most critical areas of the EU customs law. It involves legal actions related to allocation of the eight-digit code to a specific unique product (type of goods), on which the amount of payable customs duty (set in the Combined Nomenclature of the European Union, see Council Regulation [EEC- European Economic Community] No. 2658/87 of 23 July 1987 on the tariff and statistical nomenclature and the Common Customs Tariff, 1987; hereinafter referred to as CN) depends. For this reason, a relatively high number of legal disputes within the European Union, especially at the national level (in the EU Member States), is usually related to the issues of correct interpretation (or the inequality of interpretation) of the content of the $\mathrm{CN}$ governing the tariff classification of goods. It is important to mention, that the empirical studies that were carried out during the analysed period (see, e.g. Javorcik, Narciso, 2013) also confirmed that the incorrect (inappropriate) tariff classification of goods is one of the most common customs duties avoidance practices on a worldwide scale. Therefore, this area receives more and more attention both at a theoretical level and at a practical level. It should be noted that such types of problems were also reflected in the practice of the Baltic States, in particular in the Republic of Latvia, namely, in Case C-382/09 (Stils Met SIA v. Valsts ienēemumu dienests, 2010) that has been examined by the CJEU. In this case, the national courts in the Republic of Latvia addressed the issue of the tariff classification of ropes and cables imported from third countries. The main legal question, which arose in the described case, was whether ropes and cables made of specific alloy steel should be classified as steel ropes and cables (CN codes 73121083 19, 7312108419 and 73121086 19) or as 'other iron products', belonging to the same heading 7312 of the $\mathrm{CN}$ but having different full eightdigit codes. The CJEU explained that in the present case, note 1 to the chapter 72 of the $\mathrm{CN}$ defines 'steel products' in general and these definitions are relevant to the whole $\mathrm{CN}$, including its section 73 . For this reason, according to the explanations of the CJEU, categories 'stainless steel' and 'other alloy steel' should be understood as special steel grades/types that should be considered as belonging to the common category of 'steel/steel products' (para. 38 of the Court's decision). Such explanation of the CJEU in its essence coincides with the theoretical assessments of the legal doctrine and jurisprudence (see, e.g. Rovetta, Gavier, 2011), which reiterated the need to refer to the title of the heading/subheading and the additional explanatory notes to the relevant section and chapter of the $\mathrm{CN}$ as a basic rule for the classification of goods. Such basic provision (i.e. the fact that the main criterion determining the correct classification of goods depends on the general characteristics of the goods described in the headings of the $\mathrm{CN}$ and the notes of its sections and chapters) has been repeatedly applied in other CJEU cases during the analysed period (since 2010), see Case C-291/11 (Staatssecretaris van Financiën v. TNT Freight Management (Amsterdam) BV, 2011). Also, the interpretations of the CJEU in Case C-382/09 
(Stils Met SIA v. Valsts ieṇēmumu dienests, 2010) are important as they emphasised another important general principle of tariff classification of goods, which must be consistently observed in the EU Member States. According to this principle, to ensure uniform tariff classification of goods, it is necessary to follow not only the notes to the sections and chapters of the $\mathrm{CN}$ but also the Explanatory Notes (Harmonized System Explanatory Notes [HSENs]) prepared by the World Customs Organization (WCO). Therefore, the HSENs (which set international standards for the uniform nomenclature of classification of goods) are also considered as essential tools for ensuring the uniform application of the EU Common Customs Tariff (see also Cases C-450/12 [HARK GmbH \& Co. KG, Kamin-und Kachelofenbau v. Hauptzollamt Duisburg, 2013] or C-635/13 [SC ALKA CO SRL v. Autoritatea Națională a Vămilor - Direcția Regională pentru Accize și Operațiuni Vamale Galați and Direcţia Generală a Finanţelor Publice a Municipiului București, 2015]). They can be used as a basis for the interpretation of the $\mathrm{CN}$ (even if they were not adopted by the EU itself as its sources of law). However, in the recent years, this position was constantly questioned by the national courts in the Republic of Lithuania (see Valantiejus, 2016). Such trend can be explained by the fact that the relevant sources of the EU customs law (e.g. the UCC and/or the Regulation [EEC] No. 2658/87) still does not include any regulations directly governing the settlement of collisions between the $\mathrm{CN}$ and the HSENs. Therefore, the establishment of such regulations can be seen as one of the directions of the further development of the EU customs law.

On the other hand, it can be added that Case C-382/09 (Stils Met SIA v. Valsts ieñēmumu dienests, 2010) has highlighted the existence of some other fundamental issues arising from the interpretation and application of the $\mathrm{CN}$. They are mainly related to the linguistic aspect of its interpretation (when it is necessary to identify what types of goods are covered by one or another general term in the $\mathrm{CN}$, as by the concept of 'steel products' in the present case). It should be emphasised that from a theoretical, comparative point of view, the attitude of different countries to the tariff classification of goods is different. Such approach can be qualified as conservative (where the application of tariff classification rules aims to ensure that as few goods as possible are classified according to their general characteristics as homogeneous goods). It can also be qualified as liberal (as many as possible types of goods are intended to be classified as homogeneous goods without further dividing them into parts or elements and specific products), see Rauch (1999). As it was confirmed by the case law of the CJEU in Case C382/09 (Stils Met SIA v. Valsts ien̄ēmumu dienests, 2010) and other similar cases (such as Case C450/12 [HARK GmbH \& Co. KG, Kamin-und Kachelofenbau v. Hauptzollamt Duisburg, 2013]), it can be concluded that the European Union has chosen to follow the liberal model of linguistic interpretation of the $\mathrm{CN}$. The same trend was also confirmed by another case in the CJEU from the Republic of Latvia, that is, Case C-286/15 (Valsts ieñēmumu dienests v. SIA 'Latvijas propāna gāze', 2016). In this case, the CJEU explained that even the mixtures of various products could be classified as homogeneous goods by taking into account both the essential properties of mixed products and other relevant factors described in the CN (para. 22-29 of the decision). Similar argumentation was also used in the previous practice of CJEU in other cases such as Case C-35/93 (Develop Dr. Eisbein GmbH \& Co. v. Hauptzollamt Stuttgart-West, 1994). In this particular case, the CJEU primarily supported the position of the EU Member State (Federative Republic of Germany) and its customs authorities, according to which goods imported in the customs territory of the European Union (in this particular - parts of copying machines) should be considered as incomplete primary goods (copying machines) and classified as such. Thus, by applying this liberal model, the final classification of goods is determined by the universal features/properties of their general type.

On the other hand, the application of such a model and such universal rules does not help to avoid the increasing number of new disputes in this area (see cases Panasonic Italia SpA, Panasonic Marketing Europe GmbH, Scerni Logistics Srl v. Agenzia delle Dogane di Milano, 2014; Agenzia delle Dogane, Ufficio di Verona dell'Agenzia delle Dogane v. ADL American Dataline Srl, 2014; Rohm Semiconductor GmbH v. Hauptzollamt Krefeld, 2014; Hauptzollamt Hannover v. Amazon EU Sàrl, 2015). Owing to the complexity of technology and the emergence of many new types of goods, mainly consisting of many different parts (elements), the constant problem related to a proper linguistic interpretation of the $\mathrm{CN}$ remains. The significance of this problem is highlighted by the fact that importers often seek to avoid payment of higher trade defense customs duties by classifying the imported goods not as a final product but only as separate parts of final goods (which are not covered by trade 
defense duties), see Vermulst (2015). It should be noted that implementation of proper tariff classification still poses significant challenges and problems at the national level (in the EU Member States, as it is evidenced by the cases originating in the Baltic States, namely, the Republic of Latvia). Such a situation exists both because of the reasons related to constant technological advances and because the classification process itself is not yet automated, it is necessary to apply additional sources for the classification (not only the $\mathrm{CN}$ itself but also in WCO documents, namely, HSENs). Therefore, proper classification requires the use of specific knowledge or expertise to interpret and apply classification rules correctly (see Laurinavičius et al., 2014). According to the authors' assessment, this problem could be addressed in the EU Member States by ensuring a much broader and more effective application of the Binding Tariff Information (BTI) Institute (Article 33 of the UCC). As the CJEU has emphasised, BTI aims to provide legal certainty to the trader when there are any doubts about the classification of goods (see Case C-153/10; Staatssecretaris van Financiën v. Sony Supply Chain Solutions [Europe] BV., 2010). Thus, the decision to issue the BTI confirms the classification of the certain types of goods according to the $\mathrm{CN}$ and protects the person (taxpayer) from any subsequent changes in the position of customs authorities regarding the classification of a specific product. It is noteworthy to mention that these goals are also being pursued by the new UCC which, for example, establishes additional procedures (see Art. 33-34 of the UCC) ensuring that decisions regarding the issuing of the BTIs in the EU Member States do not differ and BTIs are issued under the same conditions. However, it should also be noted that even the existing legal framework does not eliminate all possible problems related to the efficiency of the BTI institute. For example, the original decision-making procedure under the provisions of the UCC remains decentralised (falls under the responsibility of an individual EU Member States), see also Limbach (2015). Therefore, there still remains a scope for different decision-making, as it is noticed by the authors in the Baltic States (Laurinavičius et al., 2014) and can be confirmed by certain practical examples, such as Case C-199/09 (Schenker SIA v. Valsts ienēmumu dienests, 2010), where the conditions related to the issuing of BTIs in Latvia were also assessed by the CJEU. Besides, under the provisions of UCC, the BTI applies only directly to the subject (person) mentioned in the decision and other related subjects (such as subsidiaries of parent company operating in certain EU Member State) cannot rely on it in the other EU Member States (Article 33, para. 2 of the UCC), see also Shu-Chien Chen (2016). Thus, it is clear that these problems could only be fully resolved in the future and only if a centralised single BTI system would be applied in all the EU Member States to all the persons concerned. In the authors' opinion, the creation of such a system is currently not possible because it requires not only the formal changes in the existing legislation. First of all, such changes should include the centralisation of the BTI system, and the creation of a single BTI procedure will require organisational and administrative changes, such as development of a centralised EU customs administration system, replacing the national customs administrations. On the other hand, the centralisation of at least individual functions of customs administration, such as the classification of goods and the issuing of BTI, and the transfer of such functions to the EU institutions can be evaluated as a positive transformation. It is important to note that the functioning of the existing BTI system (taking into account the inefficiency of cooperation between the Member States) has been widely criticised by both the EU Commission and other institutions such as the Court of Auditors (see Binding Tariff Information [BTI] - efficiency and new working methods. Note to the CPG 27, 2011; Court of Auditors, Special report No. 2/2008 on binding tariff information with the answers of the Commission, 2008).

Whilst analysing other specific cases regarding the tariff classification of goods that were originated in the Republic of Latvia and were later settled by the CJEU, it can be observed that they reveal some other general and fundamental (constitutional) problems of the EU law. Such cases include, in particular, Case C-558/11 (SIA 'Kurcums metal' v. Valsts ieņēmumu dienests, 2012) and Cases C-233/15 (SIA 'Oniors Bio' v. Valsts ien̄ēmumu dienests, 2016) as well as C-547/13 (SIA 'Oliver Medical' v. Valsts ieņēmumu dienests, 2015). Similarly as analogous/related disputes in other new EU Member States (not only in the Baltic States, see e.g. case C-180/12 (Stoilov I Ko EOOD v. Nachalnik na Mitnitsa Stolichna, 2013), the described category of cases raises questions about the functioning and effectiveness of the national courts in the EU Member States and the cooperation mechanism between them and the CJEU itself. For example, in Case C-558/11 (SIA 'Kurcums metal' v. Valsts ienēmumu dienests, 2012), the Supreme Court of the Republic of Latvia (Augstākās tiesas Senāts) applied to the CJEU for the clarification of the attribution of specific classification codes to certain types of goods (wire ropes and fasteners). The 
CJEU stated that 'when the Court is requested to give a preliminary ruling on a matter of tariff classification, its task is to provide the national court with guidance on the criteria which will enable that court to classify the goods at issue correctly in the $\mathrm{CN}$, rather than to effect that classification itself' (para. 28 of the decision).

On the other hand, the final judgment of the CJEU, in this case, does not fully comply with this explanation. For example, in the final (operative) part of the judgment, the Court nevertheless clarified and explained which specific eight-digit tariff classification code/subheading should apply to the product in question (e.g. 560749 11, 731700 90). Therefore, the Court described the final tariff classification code of goods (according to the content of the $\mathrm{CN}$ ) and not limited itself to describe only the essential criteria for classifying the goods. Such example of the CJEU practice essentially confirms that in some individual tariff classification cases, the principle of cooperation between national courts of the EU Member States and the CJEU (which is currently enshrined in Article 267 of the Treaty on the Functioning of the European Union, 2012; hereinafter - TFEU) on the practical level is interpreted in a rather specific way. In this case, the national courts were not only provided with guidance regarding the interpretation of the substantive law based on which the national court should decide the case.

On the contrary, the CJEU itself applied the law to the specific facts, that is, reserved the right to clarify itself the issue of final classification of goods in the disputes regarding their classification code. Such position of the CJEU in the legal doctrine (see Barnard, 2016; Limbach, 2015) is described based on pragmatism and the need to ensure a uniform interpretation of the EU law - the factors that have traditionally been emphasised in other cases dealt by the CJEU and at the academic level as well. However, according to the authors' opinion, it also creates some problematic issues, for example, whether the examining of the specific technical issues related to the classification of individual goods is compatible with the primary mission of the CJEU, as it is described in the TFEU (see, e.g. Art. 267).

It should be noted that the assignment of a proper, accurate full product tariff classification code may require a specific expert assessment of physicochemical or physical properties of goods as well as laboratory tests (Gurevičienè, 2005). Therefore, such investigations can only be provided by the specialised national authorities such as customs laboratories, and in many cases, there is no possibility of conducting such investigation whilst the case is settled in the CJEU. However, as it can be seen from the case law of the CJEU, in cases falling within the topic under investigation (i.e. tariff classification cases originating from the Baltic States, i.e. the Republic of Latvia), the position of the CJEU itself on this issue remains inconsistent. For example, in Case C-558/11 (SIA 'Kurcums metal' v. Valsts ieñēmumu dienests, 2012), the CJEU has emphasised the need to distinguish itself (as the judicial institution of the European Union) as much as possible from performing the tariff classification of goods and stressed the need to fulfill only the function of interpretation of law. However, only in some of the cases (e.g. C-233/15 [SIA „Oniors Bio" v. Valsts ien̄ēmumu dienests, 2016]; C-547/13 [SIA 'Oliver Medical' v. Valsts ieñēmumu dienests, 2015]), the CJEU refrained from explanation of the final specific eight-digit tariff classification code applied to goods in question and provided only general clarifications (guidelines for the interpretation of the law) regarding the provisions of the $\mathrm{CN}$.

In the authors' opinion, such situation involving above-mentioned legal inconsistencies and the transfer of technical disputes regarding the calculation of customs duties to the level of the CJEU cannot be solved by merely limiting the possibility for national courts to refer to the CJEU with the questions regarding the interpretation of the $\mathrm{CN}$. Such a strict position could be evaluated as unreasonable and could give rise to numerous legal discussions (Craig, 2010; Turičnik, 2014). On the other hand, this problem could be solved by the CJEU itself in its practice. It can be done by distinguishing more specific criteria explaining when it is necessary to provide clarification on the attribution of a specific $\mathrm{CN}$ code and when only general explanations should be provided, such as explanations involving only the assignment of a product/good in question to the relevant chapter, heading or subheading of the EU Combined Nomenclature. Therefore, the determination of a specific code should be attributed to the competence of the national court (and other national tax authorities and tax administrations). Also, as a more specific alternative to these measures, the revision of the existing legal framework could be considered. For example, it is possible to impose imperatively (in the Combined Nomenclature of the European Union) that the competent authorities of the EU Member States themselves are responsible 
for the proper classification of goods and assignment of their eight-digit tariff classification codes (the authors suggest to establish such rule in the Art. 12 of the Regulation [EU] No. 2658/87, 1987).

Another issue raised in Case C-558/11 (SIA 'Kurcums metal' v. Valsts ien̄ēmumu dienests, 2012) could be related to the problems of linguistic interpretation of the EU customs legislation (in this particular case - provisions of the Council Regulation [EC] of 2 August, 2001, No. 1601/2001, which imposed definitive anti-dumping duties on imports of certain iron or steel ropes and cables originating, inter alia, in Russian Federation). In the present case, one of the essential arguments of the applicant (importer of goods), SIA Kurcums Metal, which imported the disputed goods (steel wire ropes) from the Russian Federation to the Republic of Latvia, was related to the fact that description of the product in question in the Latvian language version of the Regulation No. 1601/2001 could be interpreted as stating that the anti-dumping duties do not apply to the products that could be classified in the subheading 73121098 of the CN. On the other hand, in the versions of the same EU regulation and its texts in other official languages of the EU Member States, the same disputed product (according to its tariff classification code) was classified as the product subject to anti-dumping duties. It is important to note that the analysis of the CJEU ruling in this case (SIA 'Kurcums metal' v. Valsts ieñēmumu dienests, 2012) confirms that this linguistic contradiction has been overcome (eliminated) by interpreting the EU law (Regulation [EC] No, 1601/2001) based on the teleological/purposive approach (method of interpretation of law). This means that the CJEU has pointed out that 'the provision in question must thus be interpreted by reference to the general scheme and the purpose of the rules of which it forms part' accordingly, in the light of the rules of Regulation No. 1601/2001 (see para. 48 and para. 50 of the Court's decision). Therefore, the Court ruled that although no reference was made to the disputed product and its code (subheading) according to the CN in the Latvian language version of the Regulation No. 1601/2001, the relevant provisions cannot be interpreted as not applicable to the importation of goods (steel wire ropes) into Latvia (as an EU Member State). On the other hand, it is vital to note that the CJEU has applied this method of interpretation only after it established the existence of the 'divergence between the various language versions' (para. 48 of the Court's decision) of the relevant source of the EU law. Thus, in the authors' opinion, it can be stated that, according to the position of the CJEU, the teleological interpretation of the EU legal regulations (on the basis of their structure and purpose) is still possible only after a literal (linguistic) analysis of the applicable legal regulation and comparison of their different linguistic versions was completed. Substantially, the same common position has also been followed in other recent cases of the CJEU, such as Case C-74/13 (GSV Kft. prieš Nemzeti Adó-és Vámhivatal Észak-Alföldi Regionális Vám-és Pénzügyőri Főigazgatósága Debreceni Közigazgatási és Munkaügyi Bíróság, 2014). The above-mentioned case was related to the interpretation of other sources of the EU customs legislation (Combined Nomenclature itself) and involved not only Baltic States (Latvia) but also other Member States of the European Union. According to the authors' opinion, the explanations of the CJEU mentioned above are undoubtedly crucial for the further development of the EU customs law in the context that they clarify the process of interpreting the EU customs legislation. It is important to note that some of the views expressed in the doctrine of law (see Broberg, 2008; Broberg and Fenger, 2014) argue that the literal interpretation of the provisions of the EU law that is carried out by comparing their different language versions in different official languages of the Union is not expedient or should be limited. Therefore, the priority should be given to a teleological/purposive (contextual) interpretation. However, it can be noted that in practice (at least in the field of customs law) such an approach is not yet dominant, nor it is universally accepted. On the other hand, greater legal certainty in this area could also be achieved by certain transformations and improvements of the EU legislation. For example, it is recommended to use a more precise definition of $\mathrm{CN}$ interpretation stages. For this reason, it is necessary to set imperative provisions that the linguistic interpretation procedure should always be considered as the first and mandatory stage of interpretation and the national institutions of the Member States (e.g. national courts) applying EU customs legislation (provisions of the $\mathrm{CN}$ ) should also follow this particular rule/order. Such provision can be included into the text of the CN itself, that is, into General rules for the interpretation of the Combined Nomenclature, Section I, chapter "A" of the CN. It is important to note that similar situations have arisen in the other Baltic States, such as the Republic of Lithuania (UAB Profisa v. Muitinès departamentas prie Lietuvos Respublikos finansu ministerijos, 2007). The existence of similar cases in the other Baltic States confirms the systemic character of this 
problem, primarily because the necessary applicable order of interpretation of the Combined Nomenclature (as the CJEU explained it to the national courts) was also similar.

1.2. Cases related to the regulation of customs procedures: Other legal issues related to customs clearance of goods imported from third countries were dealt with by the CJEU in Case C-571/12 (Greencarrier Freight Services Latvia SIA v. Valsts ienēemumu dienests, 2014). In the case mentioned above, which was referred to the CJEU for a preliminary ruling by the national court in Latvia, the CJEU assessed the legal situation in which the taxpayer Greencarrier Freight Services Latvia re-imported biscuits and chocolate bars into the territory of the Republic of Latvia for a release for free circulation in the European Union. In this case, the Latvian State Tax Administration, based on the results of the partial verification of the goods indicated in the subsequent customs declarations, carried out documentary checks on identical imported goods that were previously imported and released for free circulation. During this procedure, the Latvian State Tax Administration have not examined the characteristics and composition of the disputed goods and found that the goods were declared by using the incorrect CN code. Accordingly, the case raised the question of the existence of the right of the customs authorities to extrapolate (transfer) the results of partial verification of the goods covered by the same declaration to the goods covered by previous declarations made by the same declarant and under what conditions? According to the authors' assessment, this problematic issue is also relevant in the context of the current application and interpretation of the provisions in the UCC, which defines the powers of the EU Member States to lay down national rules on customs clearance procedures and to adjust their content. It is important to mention that the EU customs law does not regulate this issue in detail, traditionally leaving it to the Member States and the discretion of their institutions. It should be noted that the response of the CJEU to this question was mostly positive. On the basis of the provisions of Article 78 of the Community Customs Code (which was in force at the time when the legal relationship of the dispute arose and which corresponds to the current Article 48 of the UCC), the CJEU has acknowledged that such extrapolation in principle was possible.

It should be noted that similar practices have been followed by courts in the other Baltic States, such as the Republic of Lithuania (especially in the cases related to the so-called 'special customs procedures' (currently listed in Article 210 of the UCC) when the goods brought into the customs territory of the European Union were later re-exported to the third countries. However, the national courts of the Republic of Lithuania in similar situations have not referred to the CJEU but solved these issues and made quite similar conclusions on a national level (see, e.g. Baronaite, 2010). It should be emphasised that such precedent of the case law (as it was formulated in Case C-571/12 [Greencarrier Freight Services Latvia SIA v. Valsts ienēmumu dienests, 2014]) allows the customs administrations to carry out a posteriori checks. Therefore, the customs administrations have the right to complete the investigation of goods that were already declared in customs by questioning the previously submitted declarations on the basis of written documents and does not have an obligation to inspect the goods in question physically. Such position is in principle also consistent with the practice that was formulated by the CJEU in other cases, such as Case C-320/11 (Digitalnet OOD and Others v. Nachalnik na Mitnicheski punkt - Varna Zapad pri Mitnitsa Varna, 2012) and Case C-290/01 (Receveur principal des douanes de Villepinte v. Derudder \& Cie SA, and Tang Frères, 2004). A similar position was also supported by the CJEU in Case C-156/16 (Tigers GmbH v. Hauptzollamt Landshut, 2017).

On the other hand, we must take into account the fact that certain assumptions for the further corrections and transformations in this practice exist after the entry into force of the UCC and in particular its provisions, regarding transfer of customs procedures into the electronic environment (Article 6 of the UCC). Therefore, the priority of formal documents as the sources of evidence is no longer emphasised. Besides, under the new provisions of the UCC (see Art. 22, 'Decisions taken upon application'), it is quite clear that new decisions of customs administrations can only be made after the individuals have been provided with more detailed information on the legal status of the results of their customs procedures and the legal possibilities of reviewing them later (a posteriori). However, to ensure practical implementation of such provisions, it is also necessary to make improvements to the legal regulations (at the national level). As it was already mentioned, such a trend was especially evidenced by the situation and cases in the Republic of Lithuania during the analysed period; however, the new Law on 
Customs of the Republic of Lithuania (2016), see Articles 29-38, does not include any imperative provisions to regulate such issues and, therefore, criticised in this respect.

1.3. Cases related to the customs valuation of goods: Whilst recognising that the primary and standard (standard) method of valuation of imported goods in the European Union is still a transaction value method (UCC, Art. 70, para. 1), we must acknowledge that there are also problematic issues in which legal situations are not required to be followed. It should be emphasised that the issues of this kind have been raised more than once in the recent practice of the CJEU, for example, Cases C-354/09 (Gaston Schul BV v Commission Staatssecretaris van Financiën, 2010), C-116/12 (Ioannis Christodoulou and Others v. Elliniko Dimosio, 2013), C-291/15 (EURO 2004. Hungary Kft. v National Tax and Customs Office Western Transdanubian Regional Customs and Finance Directorate, 2016) and, in particular, also in the cases originating from the Republic of Latvia, Case C-430/14 (State Revenue Service v. Arthur Stretinski, 2016). Whilst in this particular case, the CJEU has once again emphasised that the transaction value method should be considered as the most important (hierarchically), such provision was once again challenged by the national courts in the Baltic States (Republic of Latvia). Especially we can notice that in situations where national tax and customs authorities sought to challenge possible tax fraud related to the diminishing of real customs value of imported goods and used other (alternative) customs valuation methods to establish the customs value of imported goods. It is necessary to note that in similar situations, as it was done in Case C-263/06 (Carboni e derivati Srl v. Ministero dell'Economia e delle Finanze and Riunione Adriatica di Sicurtà SpA, 2008), para. 64, the CJEU emphasised the need to guarantee the importer's right to be heard when the customs authorities took the decision not to apply the transaction value method to calculate the customs value of the goods but also calculated it by other alternative methods. This conceptual provision was further developed in the latest case of Latvian origin: C-46/16 (Valsts ienēemumu dienests v. "LS Customs Services", 2017). Here the CJEU stated that the importer has the right to know on what basis other specific (alternative) methods were chosen if the transaction value method was not applied, that is, why the customs authorities 'set aside one or more methods for determining customs value' (para. 44-45, 47). In other words, these precedents developed by the CJEU attempted to clarify the exceptions to the application of the transaction value method in the EU customs law. At the same time, they can also be seen as an attempt to provide broader safeguards of the right to defense (aligned with the Article 41 of the EU Charter of Fundamental Rights, 2012) and the right to proper administration. Such safeguards are binding not only on the Union itself but also on Member States in situations where national customs authorities need to deviate from the presumption of application of the transaction value method (as it was done by the authorities in the Republic of Latvia in the cases mentioned above). However, according to the author's assessment, it can be seen that this area of legal regulation that is mentioned remains particularly significant, especially because there is an increasing debate about the legality of appropriate anti-avoidance measures in taxation (LasińskiSulecki, 2015). Therefore, to ensure the consistent practice of the application of such measures, the above-mentioned procedural rights of importers (taxpayers) should be directly enshrined in the regulation that implements the UCC (e.g. Art. 144 of the Regulation [EU] No. 2015/2447). General problematic nature of similar issues is also confirmed by the case law of the Lithuanian courts (Giriūnienè et al., 2016). However, the problem is that they have chosen different reasoning of their decisions in such situations (regarding priority of transaction value method). These decisions were not based on the EU law but on direct application of the World Trade Organization (WTO) law (see, e.g. the Supreme Administrative Court of Lithuania, 5 March 2013 decision in the administrative case No. A-442-709/2013, 2013). Such legal reasoning may be considered a problem because it may contradict the general attitude of the CJEU to the relationship between the WTO and the EU legal orders (for further details on this issue, see Katuoka, Valantiejus, 2017).

1.4. Cases related to the origin of the custom of goods: One of the fundamental problems of the EU customs law, reflected in the practice of the CJEU is how to interpret the criteria for the determination of origin of imported goods. The second most important problem is how the burden of proof should be shared between the importer and the customs authorities in such situations (see, e.g. Case C-373/08, Hoesch Metals and Alloys GmbH v. Hauptzollamt Aachen, 2010). Therefore, usually in such cases, the CJEU receives questions such as should the process of determining the origin of the custom of the goods by the national customs authorities always be based on evidence (certificates, documents) issued by the country from which the goods were imported? In which cases, the customs authorities of the EU Member 
State of origin have the right to challenge the legality (admissibility) and reasonableness of the evidence provided by the same importer and to consider other additional evidence sources proving the customs origin at its discretion (ex officio)? This problem is particularly relevant in the sense that, as is apparent from the legal doctrine, rules of origin can also be used for trade defense purposes. For example, instead of initiating a new investigation on the application of trade defense instruments (anti-dumping duties), the customs authorities of an EU Member State may challenge the declared preferential origin of the goods in question (Vermulst, 2008). For this reason, many disputes have arisen in this area in the EU Member States, including the Baltic States, such as Latvia (see arguments below) and Lithuania (see Valantiejus, 2016), especially given the fact that the EU legal framework is rather vague in this area.

It should be emphasised that after the decision of the CJEU in Case C-438/11, Lagura Vermögensverwaltung (para. 28-33), new practice began to take shape in this area. According to the explanations of the CJEU, in such legal situations where a third country from which the goods were imported, was subject to preferential tariffs and the taxpayer (importer of such goods) was acting in good faith, the origin of those goods may still be challenged later. The customs authorities may carry out additional verification by investigating whether possibly false information was provided by the exporter in the customs declaration and certificates of the origin of goods. It should be noted that, in principle, similar conclusions previously were also made in Case C-409/10 (Hauptzollamt HamburgHafen v. Afasia Knits Deutschland GmbH, 2011), see para. 48 of the Court's decision. In this particular case, the CJEU stated that the issue of a specific certificate proving the customs origin of the goods cannot be qualified as an error made by the customs authorities, which does not give rise to the registration of customs debt (Community Customs Code, Article 220, para. 'b', which corresponds to the Article 119, para. 1, of the UCC). This provision shall apply in the event when these certificates were based on the false information provided by the exporter unless the authorities which issued such certificates were aware or should have been aware that the goods do not correspond to the conditions required for their preferential treatment. It is essential that similar questions related to similar circumstances were referred to the CJEU by the national courts in the Republic of Latvia (see e. g. case C-47/16 (Valsts ieñēmumu dienests v. "Veloserviss" SIA, 2017)). In the judgement that was adopted in this case, the CJEU stated that importer is obliged to verify the circumstances under which the origin certificate of goods was issued. For example, the importer has to verify the circumstances under which the export customs authorities in the exporting state issued such certificates as well as contribution of the exporter to the production of goods, in case if there are apparent reasons that raise doubts about the accuracy of the certificates of origin (para. 39 of the Court's decision). Thus, in this aspect, as it can be seen from Case C-438/11 (Lagura Vermögensverwaltung v. Hauptzollamt Hamburg-Hafen, 2012), the final position of the CJEU is such that the circumstances under which the importer can be exempted from the customs duties that were calculated because of inappropriately declared origin of goods should be interpreted narrowly and should be associated with a number of binding cumulative conditions. The most important of them is that the importer has to act in good faith and to check any doubts related to the issuing of certificates of customs origin/documents proving the origin of the custom. On the other hand, such a position has a subjective and evaluative nature as all the responsibility is transferred to the importer, which may not have any access to legal information collected in a foreign country. However, taking into account that application of such practice differs in the EU Member States (inter alia, the Baltic States, such as also the Republic of Lithuania, see Valantiejus, 2016), it is advisable to adjust the provisions of the UCC concerning the proof of origin of goods (Art. 64). At present, the UCC regulates only the duty to prove the non-preferential origin of goods and do not provide any such general provisions applicable to situations when it is necessary to determine the preferential origin of the goods (see e.g. Art. 61 of the UCC).

\section{2-3. Cases involving the Republic of Lithuania and the Republic of Estonia.}

2-3(1). Cases related to the regulation of exemptions from customs duties: it should be emphasised that one part of the cases involving the Baltic States such as Estonia and Lithuania was related to the explanation of the concept of customs debtor and the possibility to exempt certain categories of such persons from the application of such duties. The problem mentioned above was assessed by the CJEU in Case C-3/13 (Baltic Agro AS v. Maksu- ja Tolliameti Ida maksu- ja tollikeskus, 2014), which directly relates to both the Republic of Lithuania and the Republic of Estonia. The applicant, in this case was the 
company 'Baltic Agro' that engaged in agricultural business in Lithuania and Estonia, and the case itself was referred to the CJEU by the national courts of the Republic of Estonia. In Case C-3/13, the referring national court asked the CJEU to ascertain whether Article 3, para. 1 of the Regulation (EC) No. 661/2008 must be interpreted as meaning that a company established in a Member State that has acquired ammonium nitrate originating in Russian Federation through the intermediary of another company established in a Member State of the European Union may be regarded as the first independent buyer of such goods in the Union. Therefore, the national court asked to explain whether such a company may benefit from the exemptions to the definitive anti-dumping customs duty imposed by the Regulation (EC) No. 661/2008 on ammonium nitrate. It is necessary to stress that the explanations provided in this case are essential to the development of the EU customs law. For example, in paragraph 24 of the judgment in Case C-3/13 (Baltic Agro AS v. Maksu- ja Tolliameti Ida maksu- ja tollikeskus, 2014), the CJEU stated that 'the exemption from anti-dumping duties may be made only under certain conditions, in cases specifically provided for, and thus constitutes an exception to the normal regime for antidumping duties. The provisions which provide for such an exemption are, therefore, to be interpreted strictly (note: highlighted by the authors)'. Such provision, which can also be distinguished from the other older and even recent cases, such as C-48/98 (Firma Söhl \& Söhlke v. Hauptzollamt Bremen, 1999; para. 52), Case C-371/09 (Commissioners for Her Majesty's Revenue and Customs v. Isaac International Limited, 2010) and even cases related to already analysed Latvian cases („Latvijas Dzelzcel̦š" VAS v. Valsts ienēemumu dienests, 2017), is now predominant in the practice of the CJEU. The described provision essentially prohibits as well as obliges customs administrations in the EU Member States to extend the conditions for the application of anti-dumping duties or even other mandatory regulatory measures (such as obligatory rules of customs procedures) unjustifiably. Therefore, in dealing with these issues, the applicable regulations should be interpreted stricto sensu. Thus, it is prohibited to apply any new exemptions that are not imperatively enshrined or to supplement the existing imperatively expressed conditions with new ones to facilitate/enhance the possibilities to apply the existing exemption, as well as to apply the different treatment of the same type of goods and persons importing them regarding the application of exemptions. It should be noted that during the analysed period, the case law of the national courts in the Republic of Lithuania (in legal cases/tax disputes regarding the calculation of anti-dumping duties) used a rather different approach for the solving of similar situations. For example, in the administrative cases No. A-261-146/2014, No. A-261144/2014 and No. A-377-556/2016, the Supreme Administrative Court of Lithuania annulled the antidumping duties calculated to the applicants/taxpayers that imported goods from the People's Republic China, on the grounds that, according to the assessment of the Court, the customs authorities did not exhaust all the means to prove their customs origin. According to the Supreme Administrative Court of Lithuania, it was the obligation of customs authorities themselves 'to prove country of origin to which the anti-dumping duty applies' (see decision of the Supreme Administrative Court of Lithuania of 30 April 2014 in the administrative case No. A-261-146/2014, 2014; ruling of the Supreme Administrative Court of Lithuania of 20 August 2014 in the administrative case No. A-261-144/2014; the decision of the Supreme Administrative Court of Lithuania of 1 September 2016 in the administrative case No. A377-556/2016). On the other hand, it should be noted that such special anti-dumping duty relief measure (possibility of exemption from such duties because customs administration is unable to prove the country of origin) is not and was not directly foreseen in the EU anti-dumping regulations or the UCC. On the contrary, the practice of the CJEU (Case C-416/15 [Selena România v. Direcția Generală Regională a Finanțelor Publice (DGRFP) București, 2016; para. 35-37] and the EU customs legislation [Art. 61 of the UCC] consistently follows the principle that the importer itself must prove the origin of the imported goods. This is also confirmed by the explanations in the already mentioned Case C-3/13 (Baltic Agro AS v. Maksu- ja Tolliameti Ida maksu- ja tollikeskus, 2014). For example, the CJEU has directly stated that 'the obligation to provide correct information in a customs declaration falls on the declarant', that is 'the principle of irrevocability of the customs declaration once it has been accepted' must be applied (see para. 43 of the Court's decision). In the context of the analysed situations mentioned above in Lithuania, this would mean that the importer who presented the customs declaration and indicated the country of origin of the product should bear all the possible negative legal consequences relating to the information contained in the customs declaration or, otherwise, should prove its correctness. It is noteworthy to mention, that the possibility to challenge the legality of the anti-dumping duties imposed 
on the importers or to interpret exemptions of customs duties/import taxes in accordance with the practice of the CJEU in the above-mentioned Lithuanian cases may also be negatively affected because of the unclear provisions of the Law on Administrative Proceedings (Article 4). The national law does not provide clear mandatory conditions under which the national courts, which settle tax disputes, are obliged to submit a preliminary reference to the CJEU itself (see also Kavalnè, Valančius, 2009). The scale of this problem can be also confirmed by the fact that the extensive interpretation of the conditions for the application of the exemptions from customs duties was once again sought and ultimately rejected by the CJEU in another case from the Republic of Lithuania (Lietuvos geležinkeliai AB v. Vilniaus teritorinè muitinė and Muitinès departamentas prie Lietuvos Respublikos finansų ministerijos, 2012).

\section{Conclusions}

During the investigation, the authors established that the problems of uniform application of the EU customs law in the Baltic States arose in areas such as tariff classification of goods, determination of the origin and value of goods (in the cases/situations involving the Republic of Latvia), regulation of customs procedures and, in particular, application of exemptions from customs duties/import taxes (in the cases/situations involving the Republic of Estonia and the Republic of Lithuania). At the same time, it was established that whilst the national courts of the Republic of Latvia have initiated the most significant number of referrals to the CJEU regarding the interpretation and application of the EU customs legislation, the national courts of the Republic of Lithuania were the least active in ensuring co-operation with the CJEU this area. Such a situation could have been caused by the improper national legal regulations (provisions of the national Law on Administrative Proceedings in the Republic of Lithuania).

The research shows that the scope of the problems related to the uniform application and interpretation of the EU customs legislation in the Baltic States justify the existence of the systemic regulatory problems not only on the national level but also on the level of EU law itself (supranational level). On the basis of the results of the research, these problems can be identified as follows: (i) the absence of the collision norms that regulates the application of different sources of law (international and the European Union) in the process of tariff classification of goods and the settlement of their contradictions; (ii) referral of technical issues of tariff classification of goods to the CJEU itself (the absence of clear obligation to resolve them at the national level); (iii) decentralised system of the decisions regarding Binding Tariff Information throughout the European Union; (iv) non-assertion of the order for the application of interpretation methods of the EU customs law. Besides, it is possible to distinguish the lack of procedural guarantees for the importers during the process of customs valuation and the lack of rules regulating the proving of preferential customs origin of goods. However, to address these issues, it is also necessary to improve specific national rules (in the context of the Republic of Lithuania). For example, it is essential to enshrine specific new provisions, especially involving procedural guarantees of the taxpayers/importers to be heard and to be informed about the legal basis of repeated customs checks and investigations against them (in the national Law on Customs). It also should be noted that because of linguistic challenges during the research, the authors have not analysed (in detail) the related national case law in Latvia and Estonia, which can be considered as particular limitation of this article and the object of further studies.

\section{References}

Baronaitè, M. (2010). Naudotų apgadintų transporto priemonių muitinio vertinimo ypatumai [Particularities of Used Damaged Motor Vehicles Evaluation for Customs Purposes]. Teisé, 77, 66-67.

Bikelis, S. (2012). Permąstant sankcijas už kontrabandą: proporcingumo problema (I). Proporcingumo principas ir bausmès už kontrabandą [Rethinking Sanctioning for Trafficking of Goods: The Problem of Proportionality (I). Issues of Confication and Tax Duties]. Teises problemos, 4(78), 5-24.

Bikelis, S. (2013). Permąstant sankcijas už kontrabandą: proporcingumo problema (II). Konfiskavimo ir mokestinių priemonių taikymo klausimai [Rethinking Sanctioning for Trafficking of Goods: The Problem of Proportionality (II). Issues of Confication and Tax Duties]. Teisès problemos, 1(79), 43-57. 
Bikelis, S. (2015). Baudžiamosios ir mokesčių teisès sankirta: atsakomybė už neteisètą praturtëjimą ir non bis indem principas [Crossroad of Criminal and Tax Law: Liability for Illicit Enrichment in the Context of Non Vis in Idem Principle]. Teisés problemos, 2(88), 54-69.

Bikelis, S., et al. (2017). Cigarečių neteisèta apyvarta: kompleksinė reiškinio ir kontrolès priemonių analizė [Illegal Turnover of Cigarettes: Complex Analysis of Phenomena and Control Measures]. Vilnius: Lietuvos teisès institutas.

Byla C-263/06, Carboni e derivati Srl v. Ministero dell'Economia e delle Finanze and Riunione Adriatica di Sicurtà SpA, 2008 E.C.R. I-01077.

Binding Tariff Information (BTI) - efificiency and new working methods. Note to the CPG 27 (2011). Brussels: TAXUD.

Broberg, M. P. (2008). Acte clair Revisited: Adapting the acte clair criteria to the demands of the times. Common Market Law Review, 45, 1383-1397.

Broberg, M. P., \& Fenger, N. (2014). Preliminary References to the European Court of Justice. Second edition. New York: Oxford University Press.

C-291/15, EURO 2004. Hungary Kft. v. National Tax and Customs Office Western Transdanubian Regional Customs and Finance Directorate, 2016 EU:C:2016:455.

C-58/14, Hauptzollamt Hannover v. Amazon EU Sàrl, 2015 EU:C:2015:385.

C-74/13, GSV Kft. prieš Nemzeti Adó-és Vámhivatal Észak-Alföldi Regionális Vám-és Pénzügyőri Főigazgatósága Debreceni Közigazgatási és Munkaügyi Bíróság, 2014 EU:C:2014:243.

Case C-116/12, Ioannis Christodoulou and Others v. Elliniko Dimosio, 2013 EU:C:2013:825.

Case C-153/10, Staatssecretaris van Financiën v. Sony Supply Chain Solutions (Europe) BV., 2010 E.C.R. I02775 .

Case C-250/11, Lietuvos geležinkeliai AB v. Vilniaus teritorinè muitinè ir Muitinès departamentas prie Lietuvos Respublikos finansų ministerijos, 2012 EU:C:2012:496.

Case C-154/16, „Latvijas Dzelzceḷš” VAS v. Valsts ieņēmumu dienests, 2017 EU:C:2017:392.

Case C-156/16, Tigers GmbH v. Hauptzollamt Landshut, 2017 EU:C:2017:754.

Case C-180/12, Stoilov i Ko EOOD v. Nachalnik na Mitnitsa Stolichna, 2013 EU:C:2013:693.

Case C-199/09, Schenker SIA v. Valsts ieņēmumu dienests, 2010 E.C.R. I-12311.

Case C-233/15, SIA „Oniors Bio" v Valsts ieņēmumu dienests, 2016 EU:C:2016:305.

Case C-250/11, Lietuvos geležinkeliai v. Vilniaus teritorinè muitinė, Muitinès departamentas prie Lietuvos Respublikos finansų ministerijos, 2012 EU:C:2012:496.

Case C-286/15, Valsts ieņēmumu dienests v. SIA "Latvijas propāna gāze", 2016 EU:C:2016:363.

Case C-290/01, Receveur principal des douanes de Villepinte v. Derudder \& Cie SA, and Tang Frères, 2004 E.C.R. $\mathrm{I}-02041$

Case C-291/11, Staatssecretaris van Financiën v. TNT Freight Management (Amsterdam) BV, 2011 EU:C:2012:459.

Case C-3/13, Baltic Agro AS v. Maksu- ja Tolliameti Ida maksu- ja tollikeskus, 2014 EU:C:2014:2227.

Case C-320/11, Digitalnet OOD and Others v. Nachalnik na Mitnicheski punkt — Varna Zapad pri Mitnitsa Varna, 2012 EU:C:2012:745

Case C-35/93, Develop Dr. Eisbein GmbH \& Co. v. Hauptzollamt Stuttgart-West, 1994 E.C.R. I-02655.

Case C-371/09, Commissioners for Her Majesty's Revenue and Customs v. Isaac International Limited, 2010 E.C.R. I-07727.

Case C-382/09, Stils Met SIA v. Valsts ieņēmumu dienests, 2010 E.C.R. I-09315.

Case C-409/10, Hauptzollamt Hamburg-Hafen v. Afasia Knits Deutschland GmbH, 2011 E.C.R. I-13331.

Case C-416/15, Selena România v. Direcția Generală Regională a Finanțelor Publice (DGRFP) București, 2016 EU:C:2016:501. 
Case C-430/14, State Revenue Service v. Arthur Stretinski, 2016 EU:C:2016:43.

Case C-438/11, Lagura Vermögensverwaltung v. Hauptzollamt Hamburg-Hafen, 2012 EU:C:2012:703.

Case C-450/12, HARK GmbH \& Co. KG, Kamin-und Kachelofenbau v. Hauptzollamt Duisburg, 2013 EU:C:2013:824.

Case C-46/16, Valsts ieṇēmumu dienests v. "LS Customs Services", 2017 EU:C:2017:839.

Case C-47/16, Valsts ien̄ēmumu dienests v. "Veloserviss" SIA, 2017 EU:C:2017:220.

Case C-472/12, Panasonic Italia SpA, Panasonic Marketing Europe GmbH, Scerni Logistics Srl v. Agenzia delle Dogane di Milano, 2014 EU:C:2014:2082.

Case C-48/98, Firma Söhl \& Söhlke v. Hauptzollamt Bremen, 1999 E.C.R. I-07877.

Case C-546/13, Agenzia delle Dogane, Ufficio di Verona dell'Agenzia delle Dogane v. ADL American Dataline Srl, 2014 EU:C:2014:2348

Case C-547/13, SIA "Oliver Medical" v. Valsts ieņēmumu dienests, 2015 EU:C:2015:139.

Case C-558/11, SIA „Kurcums metal“ v. Valsts ien̄ēmumu dienests, 2012 EU:C:2012:721.

Case C-571/12, Greencarrier Freight Services Latvia SIA v. Valsts ieņēmumu dienests, 2014 EU:C:2014:102.

Case C-595/11, Steinel Vertrieb GmbH v. Hauptzollamt Bielefeld, 2013 EU:C:2013:251.

Case C-63/06, UAB Profisa v. Muitinès departamentas prie Lietuvos Respublikos finansų ministerijos, 2007 E.C.R. I-03239.

Case C-635/13, SC ALKA CO SRL v. Autoritatea Națională a Vămilor - Direcția Regională pentru Accize și Operațiuni Vamale Galați and Direcţia Generală a Finanţelor Publice a Municipiului București, 2015 EU:C:2015:268.

Case C-666/13, Rohm Semiconductor GmbH v. Hauptzollamt Krefeld, 2014 EU:C:2014:2388.

Case Case C-354/09, Gaston Schul BV v. Commission Staatssecretaris van Financiën, 2010 E.C.R. I-07449.

Case Case C-373/08, Hoesch Metals and Alloys GmbH v. Hauptzollamt Aachen, 2010 E.C.R. I-00951.

Communication from the Commission to the European Parliament, the Council and the European Economic and Social Committee "On the State of Customs Union”, COM(2012) 791 final. (2012). [Accessed 20.04.2019]. Available from Internet: http://eur-lex.europa.eu/legal-content/LT/TXT/HTML/?uri=CELEX:52012DC0791\& from=lt.

Council Regulation (EEC) No 2658/87 of 23 July 1987 on the tariff and statistical nomenclature and on the Common Customs Tariff (1987). Official Journal, L 256.

Court of Auditors (2008). Special report No. 2/2008 on binding tariff information with the answers of the Commission. Official Journal, C 103/01.

Craig, P. (2010). The Classics of EU Law Revisited: CILFIT and Foto-Frost. The Past and Future of EU Law: the Classics of EU Law Revisited on the 50th Anniversary of the Rome Treaty. Oxford: Hart Publishing.

Craig, P., \& de Burca, G. (2015). EU Law: Text, Cases, and Materials. Oxford: Oxford University Press.

Decision of the Supreme Administrative Court of Lithuania of 30 April 2014 in the administrative case No. A261-146/2014. Available from Internet: 〈https://eteismai.lt/byla/86557037859732/A-261-146-14>.

Decision of the Supreme Administrative Court of Lithuania of 1 September 2016 in the administrative case No. A-377-556/2016. Available from Internet: 〈https://eteismai.lt/byla/151489826098556/A-377-556/2016>.

Decision of the Supreme Administrative Court of Lithuania, 5 March 2013 in the administrative case No. A-442709/2013, 2013. . Available from Internet: <http://liteko. teismai.lt/viesasprendimupaieska/detali paieska.aspx? detali=2>.

Díaz Gavier, P., \& Rovetta, D. (2011). A Survey of the EU Tariff Classification Case Law in Year 2010. Global Trade and Customs Journal, 6(7), 319-324.

EU Charter of Fundamental Rights (2012). Official Journal, C 326. 
EU Monitor. (2012). „Explanatory Memorandum to COM(2012)64 - Union Customs Code“. [Accessed 15.04.2019]. Available from Internet: https://www.eumonitor.eu/9353000/1/j4nvhdfdk3hydzq_j9vvik7m $1 \mathrm{c} 3 \mathrm{gyxp} / \mathrm{vix} 6 \mathrm{t} 9 \mathrm{sb} 46 \mathrm{yj}$.

Giriūnienè, G., et al. (2016). VAT Fraud in EU. Vilnius: Mykolo Romerio universitetas.

Gurevičienè, J. (2005). Tarifinio prekių klasifikavimo sistema [Tariff Classification Work System]. Jurisprudence, $73(65), 39-47$.

Javorcik, B. S., \& Narciso, G. (2013). Accession to the World Trade Organization and Tariff Evasion. CEPR Discussion Paper No. DP9592, 1-27.

Valantiejus, G. \& Katuoka, S. (2017). Application of the WTO Agreements in National Courts: Comparative Aspects of Worldwide and Lithuanian Judicial Practices. International Comparative Jurisprudence, 3(2): 195212.

Kolliker, A. (2006). Flexibility and European Unification: The Logic of Differentiated Integration. Oxford: Oxford University Press.

Lasiński-Sulecki, K. (2015). Will the Court of Justice apply its anti-abuse doctrine in customs valuation cases? World Customs Journal, 9(2), 3-11.

Laurinavičius, A., et al. (2014). Muitine tarptautinès prekybos logistinè grandineje [Customs in International Trade Logistical Chain]. Vilnius: Mykolo Romerio universitetas.

Lietuvos Respublikos mokesčiu administravimo įstatymas [the Law on Tax Administration of the Republic of Lithuania] (2004). Valstybès žinios, 63 (2243).

Lietuvos Respublikos muitinès ịstatymas [Law on Customs of the Republic of Lithuania] (2016). Register of Legal Acts, 26857.

Limbach, K. (2015). Uniformity of Customs Administration in the European Union. Oxford: Hart Publishing.

Lyons, T. (2018). EU Customs Law. Oxford: Oxford University Press.

Lučinskienè, A., \& Rimkus, V. Mokestinių sutarčių vieta tarptautinio apmokestinimo teisinio reguliavimo šaltinių hierarchijoje [Position and Role of Tax Treaties in the Hierarchy of the Sources of Legal Regulation on International Taxation]. Societal Studies 3, 7 (2010): 197-211.

Lukas, M. (2013). Valstybių konkurencijos mokesčiais ịtaka nacionaliniam mokesčiu teisiniam reguliavimui [The influence of international tax competition on national tax legislation] (doctoral dissertation). Available from Internet: http://talpykla.elaba.It/elaba-fedora/objects/elaba:1922808/ datastreams/MAIN/content.

Lukas, M., Medeliené, A. \& Paulauskas, A. (2014). Impact of Membership in the European Union on the Lithuanian National Taxation System, From G. Švedas (ed.), Lithuanian Legal System under the Influence of European Union Law: Collection of Scientific Articles (p. 499-543). Vilnius: Faculty of Law, Vilnius University.

Medelienè, A. (2012). Principai, kaip mokesčių teisès normų aiškinimo ir taikymo instrumentas nagrinejjant mokestinius ginčus [Principles as an Instrument for Interpreting and Applying Tax Law in Tax Disputes], From G., Švedas (ed.), Nepriklausomos Lietuvos teisé: praeitis, dabartis ir ateitis: recenzuotu moksliniu straipsniu rinkinys (p. 321-343). Vilnius: Vilniaus universitetas.

Medelienè, A., \& Paulauskas, A. (2008). Sandorio vertė kaip prekių muitinio įvertinimo pagrindas [Transaction Value as a Key Concept of Customs Valuation]. Teise 67, 25-47.

Medelienè, A., \& Vasiliauskas, V. (2012). Europos Sajungos teisės taikymas nagrinèjant mokestinius ginčus Lietuvoje [The Application of European Union Law in Tax Disputes in Lithuania], From V. Valančius (ed.), Žmogus, teisine valstybe ir administracine justicija: mokslo studija, skirta Lietuvos vyriausiojo administracinio teismo dešimtmečiui (p. 700-733). Vilnius: Lietuvos vyriausiasis administracinis teismas.

Milinis, A., \& Pranevičienè, K. (2016). Conditions and Circumstances which Lead to Application to the Court of Justice of the European Union and Adoption of a Preliminary Ruling. Baltic Journal of Law \& Politics, 9(2), 130149.

Novačkova, D. (2013). International Trade Economic Measures Applied in Slovakia. Czech Yearbook of International Law, IV, 143-159.

Patton, M. Q. (1990). Qualitative Evaluation and Research Methods (2nd. ed.). Newbury Park, CA: Sage. 
Puzinskaitė, E. (2013). Mokesčio apskaičiavimas taikant turinio viršenybės prieš formą principą [Tax Calculation Using the Principle of Substance Over Form]. Jurisprudence, 20(4), 1409-1426.

Puzinskaitė, E., \& Klišauskas, R. (2012). Mokesčių teisès sistema ir apmokestinimo principai [Tax Law System and Charging Principles]. Jurisprudence, 19(2), 675-695.

Radžiukynas, J. (2003). Kai kurios importuojamų prekių muitinės vertės nustatymo problemos [Certain Problems on Customs Valuation of Import Goods]. Jurisprudence 46(38), 98-107.

Radžiukynas, J. (2005). Importuojamų prekių muitinio įvertinimo kontrolè Lietuvos muitinėje Europos Bendrijos muitiniu strategijos kontekste [Customs Valuation Control of Imported Goods in The Lithuanian Customs in the Context of Customs Strategy of EU]. Jurisprudence, 73(65), 48-57.

Radžiukynas, J., \& Belzus, A. (2008). Importuojamu prekiu muitinis ivertinimas ir kontrole [Customs Valuation and Control of Imported Goods]. Vilnius: Lietuvos pramonès, prekybos ir amatų rūmų asociacija.

Rauch, J. E. (1999). Networks Versus Markets in International Trade. Journal of International Economics 48, $7-$ 35 .

Regulation No. 952/2013 of the European Parliament and of the Council of 9 October 2013 laying down the Union Customs Code. (2013). Official Journal, L 269/1.

Rodriguez, E. V., \& Dulguerova, E. (2013) Blues at the Border: The Quest for Uniform Tariff Classification in the European Union. Global Trade and Customs Journal, 8(11), 368-381.

Ruling of the Supreme Administrative Court of Lithuania of 20 August 2014 in the administrative case No. A261-144/2014. Available from Internet: 〈https://eteismai.lt/byla/50951964777036/A-261-144-14〉.

Sarapinienè, S., \& Avižienis, J. Š. Muitinès procedūros [Customs Procedures]. Vilnius: Mykolo Romerio universitetas.

Shu-Chien, C. (2016). In the name of legal certainty? Comparison of advance ruling systems for tariff classification in the European Union, China and Taiwan. World Customs Journal, 10(2), 47-64

Treaty on the Functioning of the European Union (2012). Official Journal, C 326.

Truel, C., \& Maganaris, E. (2015). Breaking the code: the impact of the Union Customs Code on international transactions. World Customs Journal, 9(2), 12-22.

Turičnik, E. (2014). Preliminary Reference Procedure - the Right, the Duty and Exceptions. InterEULawEast: Journal for the International and European Law, Economics and Market Integrations, 1(1), 1-18.

Valančius, V., \& Kavalnè, S. (2009). Europos Sajungos teisès igyvendinimas Lietuvos administracineje teisejje: monografija [Implementation of European Union Law in Lithuanian Administrative Law: Monograph]. Vilnius: Registrų centras.

Valantiejus, G. (2016). Application of Soft Law Instruments in International Economic Law: Insights on the Lithuanian Practice on the Legal Regulation of Customs Duties. Social Transformations in Contemporary Society 4, 97-108.

Valantiejus, G. (2016). Application of Rules on Burden of Proving the Customs Origin of Imported Goods in International Trade: Problematic Aspects in Lithuania. Whither our economies - 2016: 5th International Scientific Conference, October 20-21, 2016; Conference Proceedings, 124-136.

Vermulst, E. (2008). Origin Rules in EU Anti-Dumping Law and Practice: An Update. Global Trade and Customs Journal, 3(10), 337-348;

Vermulst, E. (2015). EU Anti-Circumvention Rules: Do They Beat the Alternative? European University Institute Working Paper RSCAS 57, 1-19.

Walsh, T. (2015). European Union Customs Code. Alphen aan den Rijn: Kluwer Law International. 